\title{
Front Matter: Volume 11396
}

, "Front Matter: Volume 11396," Proc. SPIE 11396, Computational Imaging V, 1139601 (20 May 2020); doi: 10.1117/12.2572602

SPIE. Event: SPIE Defense + Commercial Sensing, 2020, Online Only 


\section{PROCEEDINGS OF SPIE}

\section{Computational Imaging $V$}

Lei Tian

Jonathan C. Petruccelli

Chrysanthe Preza

Editors

27 April - 8 May 2020

Online Only, United States

Sponsored and Published by

SPIE 
The papers in this volume were part of the technical conference cited on the cover and title page. Papers were selected and subject to review by the editors and conference program committee. Some conference presentations may not be available for publication. Additional papers and presentation recordings may be available online in the SPIE Digital Library at SPIEDigitalLibrary.org.

The papers reflect the work and thoughts of the authors and are published herein as submitted. The publisher is not responsible for the validity of the information or for any outcomes resulting from reliance thereon.

Please use the following format to cite material from these proceedings:

Author(s), "Title of Paper," in Computational Imaging V, edited by Lei Tian, Jonathan C. Petruccelli, Chrysanthe Preza, Proceedings of SPIE Vol. 11396 (SPIE, Bellingham, WA, 2020) Seven-digit Article CID Number.

ISSN: 0277-786X

ISSN: 1996-756X (electronic)

ISBN: 9781510635692

ISBN: 9781510635708 (electronic)

Published by

SPIE

P.O. Box 10, Bellingham, Washington 98227-0010 USA

Telephone +1 3606763290 (Pacific Time) · Fax +1 3606471445

SPIE.org

Copyright (C) 2020, Society of Photo-Optical Instrumentation Engineers.

Copying of material in this book for internal or personal use, or for the internal or personal use of specific clients, beyond the fair use provisions granted by the U.S. Copyright Law is authorized by SPIE subject to payment of copying fees. The Transactional Reporting Service base fee for this volume is $\$ 21.00$ per article (or portion thereof), which should be paid directly to the Copyright Clearance Center (CCC), 222 Rosewood Drive, Danvers, MA 01923. Payment may also be made electronically through CCC Online at copyright.com. Other copying for republication, resale, advertising or promotion, or any form of systematic or multiple reproduction of any material in this book is prohibited except with permission in writing from the publisher. The CCC fee code is 0277$786 \mathrm{X} / 20 / \$ 21.00$.

Printed in the United States of America by Curran Associates, Inc., under license from SPIE.

Publication of record for individual papers is online in the SPIE Digital Library.

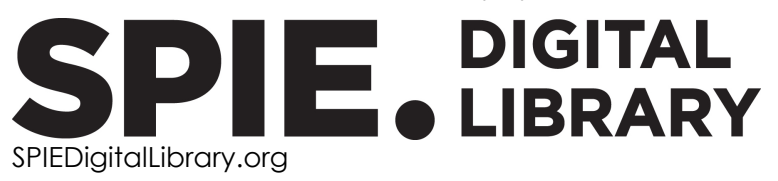

Paper Numbering: Proceedings of SPIE follow an e-First publication model. A unique citation identifier (CID) number is assigned to each article at the time of publication. Utilization of CIDs allows articles to be fully citable as soon as they are published online, and connects the same identifier to all online and print versions of the publication. SPIE uses a seven-digit CID article numbering system structured as follows:

- The first five digits correspond to the SPIE volume number.

- The last two digits indicate publication order within the volume using a Base 36 numbering system employing both numerals and letters. These two-number sets start with 00, 01, 02, 03, 04, $05,06,07,08,09,0 A, 0 B \ldots$. OZ, followed by 10-1Z, 20-2Z, etc. The CID Number appears on each page of the manuscript. 


\section{Contents}

AI IN COMPUTATIONAL IMAGING

1139603 A data-driven approach to sampling matrix selection for compressive sensing [11396-2]

UNCONVENTIONAL COMPUTATIONAL IMAGING

1139607 Computational reconfigurable imaging spectrometer (CRISP) (Invited Paper) [1 1396-6]

COMPUTATIONAL IMAGING IN BIOMEDICAL IMAGING

$113960 \mathrm{~A}$ Extended retinex and optimized image sharpening for hidden detail uncovering, visual range improvement, and image enhancement [11396-10]

COMPUTATIONAL SPATIO-TEMPORAL IMAGING

11396 OB Blending physics with artificial intelligence (Invited Paper) [11396-11]

COMPUTATIONAL MICROSCOPY

11396 Ol 3D deconvolution in Fourier integral microscopy [11396-18]

COMPRESSIVE IMAGING

$11396 \mathrm{ON} \quad$ Hardware parallel architecture proposed to accelerate the orthogonal matching pursuit compressive sensing reconstruction [11396-23]

COMPUTATIONAL IMAGING WITH DIFFRACTIVE OPTICS

1139600 Compact vortex wavefront coding camera (Invited Paper) [11396-24]

11396 OP A computational super-resolution technique based on coded aperture imaging [11396-25] 
$113960 Q \quad$ Total variation vs L1 regularization: a comparison of compressive sensing optimization methods for chemical detection [1 1396-26]

11396 OR Experimental demonstration of multi-spectral imaging of vegetation with a diffractive plenoptic camera [11396-27]

11396 OS A generalized approach for digital holographic recording and reconstruction [1 1396-28] 